\title{
MATHEMATICAL AND FUZZY LOGIC MODELS IN PREDICTION OF GEOLOGICAL AND GEOMECHANICAL PROPERTIES OF ROCK MASS BY EXCAVATION DATA ON UNDERGROUND WORKS
}

\author{
Susana Torno ${ }^{1}$, Javier Toraño ${ }^{2}$, Mario Menéndez ${ }^{3}$, Malcolm Gent ${ }^{4}$, Judith Velasco ${ }^{5}$ \\ Oviedo School of Mines, University of Oviedo, Department of Mine Explotation and Exploration, \\ Independencia 13, 30004 Oviedo, Spain \\ E-mail: ${ }^{1}$ tornosusana@uniovi.es, ${ }^{2} j$ ta@uniovi.es (corresponding author); \\ ${ }^{3}$ mariom@uniovi.es; ${ }^{4}$ gentmalcolm@uniovi.es; jvelasco@uniovi.es \\ Received 28 Apr. 2009; accepted 30 Jul. 2010
}

\begin{abstract}
In underground works, the continual consciousness of geological and geomechanical properties of rock mass during drilling, is of major importance to optimize the works and the equipment used. In this paper, the mathematical relationship obtained from tunnel excavations, considering percussion drilling for blasting by a drilling machine and by a tunnel boring machine (TBM) are exposed. These mathematical relationships are useful in the percussion drilling case, to adjust the drilling parameter recorder (DPR) tools, and in the case of TBM to predict the rock mass geomechanical index (RMR). Taking into account the complexity of these mathematical models obtained, as a consequence of the affected variables and their relations, a fuzzy logic model based on parameters accessible to the drilling machine has been used in tricone bit drilling.
\end{abstract}

Keywords: fuzzy logic, tunnel boring machine, drilling parameter recorder, tricone bit.

\section{Introduction}

The drilling parameter measurements were introduced in geological prospecting and in the mining, petrol and gas industry in the 70s, becoming an efficient tool, allowing us to identify in detail and predict the geological and geomechanical characteristics while drilling is being carried out. The field measurements and the calibration requirements of the tools and equipment used constitute the main obstacle to obtain prediction models.

Teale (1965) introduced the specific energy concept as the necessary energy required to excavate a unit rock volume and establish that it can be used as a mechanical property index of the rock mass. Peck (1989), in drill hole blasting, also established a relationship between specific energy and rock properties. The correlation between the drilling parameters and the geological characteristics of rock mass in drill hole blasting in coal mining, was tested by Scoble et al. (1989), who demonstrated, the relationships between the penetration velocity variation, the rotation torque variation, the rotation velocity, the specific cut energy and the rock characteristics.

It is important to emphasize Schunnesson (1997) research, who established that the correlation between the obtained parameters from the drilling equipment monitoring and rock characteristics (Viscara copper mine, Sweden) is not direct. The correlation may not occur when the drilling crosses broken rocks or in the case of no typical rock. He finally indicates that external factors such as the tricone bit and the different string bar parts can influence the drilling parameters.
Turtola (2001) through the geological data interpretation DPR (Drilling Parameters Recorder) obtained from rotation drilling in drill hole blasting, (copper open pit mine in Aitik Sweden), identifies the main rock types, based on the penetration velocity variation. A good relationship between different rock types and specific energy values was also shown.

Likewise, Mozaffari (2007) by using the latter data register system, together with an image analysis system through a project carried out in Aitik mine, concluded that the penetration velocity measurement, the rotation torque and the specific energy while boring, provide relevant information about mechanic properties of rock mass.

Based on revised literature, we have come to the conclusion that data registers during boring (DPR) are systems in which the calibration 'in situ' together with other relations between variables are needed to obtain a good interpretation. In tunnel boring through TBM, it is difficult to predict the geomechanical conditions of rock mass in front of the machine owing to the observation difficulties and the large number of variables which control the excavation process. Geomechanical properties prediction methods of rock mass have been developed by machine operation parameters and geological - geotechnical tunnel profiles (Rostami et al. 1996; Ozdemir 2003).

Fuzzy Logic models are other important tools used in geological and geomechanical property evaluation in hole drilling (Grima 2000). Multiple variables such as geological and geomechanical static and dynamic properties of rock mass, static and dynamic equipment and ma- 
chinery characteristics take part in mining and civil works drilling (Toraño et al. 2008). Consequently, this makes the deep rock behaviour modelling in real time difficult through mathematical models, having to resort to qualitative models based on the operator experience.

When the mathematical modelling is not possible we should resort to both fuzzy variables and fuzzy rules formulation (Nguyen et al. 1995; Kala 2008; Raue et al. 2009). Fuzzy logic allows to represent the common knowledge in a special mathematical language with the possibility of a reinterpretation of the final results through a mathematical nature process (Godo et al. 1989).

A fuzzy model in tricone bit drilling which was adjusted (based on data obtained by geological and mining exploration drilling), has been elaborated. The revolutions per minute, the pressure and the drilling diameter have been used as input linguistic variables and the rock mass quality expressed according to compressive strength in MPa has been used as an output variable. The latter model adjusted and the existent correlation grade between this model and field data are shown.

\section{Underground Excavations. Mathematical Models}

\subsection{Parameters for Percussion Drilling and TBM Excavation}

Teale (1965), besides, to introduce the specific energy concept in rotation drilling, indicated that the work process carried out in the rock breaking in each volume unit was related to the uniaxial compressive strength of that rock. Further research in this field has been carried out by Mellor (1972), Reddish and Yasar (1996), Ersoy (2003) and others.

Two types of specific energy can be distinguished in the rotation drilling, the one required to move a rock volume unit during rotation drilling (SEv) (Teale 1965) and the energy to generate a new surface area (SEa) (Paithankar and Misra 1976). Specific energy is a cut mechanic efficiency index and can be considered as the sum of both the pressure energy strength $e_{t}$ and the rotation energy $e_{r}$ :

$$
\begin{gathered}
e_{t}=\frac{F}{A} \mathrm{~kJ} / \mathrm{m}^{3}, \\
e_{r}=\left(\frac{2 \pi}{A}\right)\left(\frac{N T}{V}\right) \mathrm{kJ} / \mathrm{m}^{3},
\end{gathered}
$$

where $F$ is the contact pressure $(\mathrm{kN}), A$ the excavated section $\left(\mathrm{m}^{2}\right), N$ the cutterhead rotation velocity $(\mathrm{rpm}), T$ the cutterhead rotation torque (kN.m) and $V$ the penetration velocity.

If $p$ is named penetration per revolution, the previous equation becomes:

$$
S E=\frac{F}{A}+\frac{2 \pi T}{A p} \mathrm{~kJ} / \mathrm{m}^{3} .
$$

The $T / p$ relation is the necessary rotation torque to drill a rock length $p$ in one revolution. Therefore, it is considered as a useful specific energy indicator.
The $W_{z}$ Specific Destruction Work $\left[\mathrm{kJ} / \mathrm{m}^{3}\right]$ is a required energy quantity measurement in the destruction, in new surface creation, or in rock cracks. This term allows the comparison between different rock materials. In Fig. 1, Young's modulus corresponds to the curve lineal slope from the starting point of the loading to the breaking point. The area under tension-deformation curve is the specific destruction work. Thuro (1997) verified, by comparing the penetration velocities of different materials with their corresponding specific destruction work, in which the specific work is a parameter that presents a good correlation with the perforation velocity.

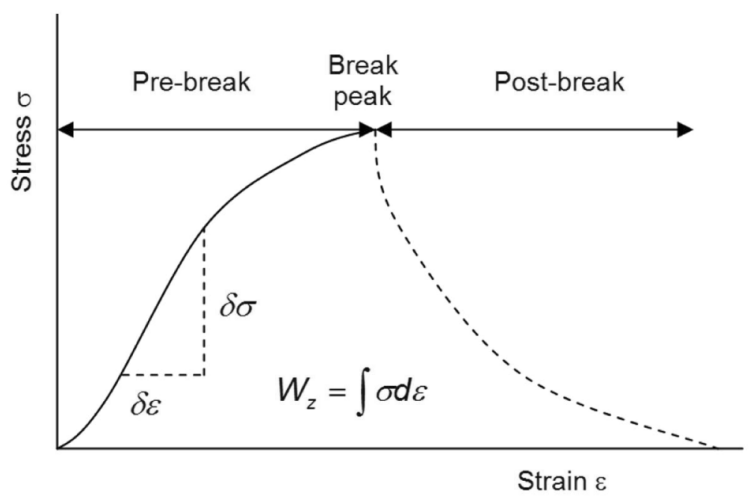

Fig. 1. $W_{z}$, specific destruction work estimation, from tension deformation curve, of a rock sample under unconfined compression

The relationship between the uniaxial compressive strength and the specific cut energy in various rock types was analyzed by Reddish and Yasar (1996). The following equation, which relates the specific energy $(S E)$ to the rock uniaxial compressive strength, was proposed:

$$
S E\left[\mathrm{MJ} / \mathrm{m}^{3}\right]=9.927(\text { UCS }[\mathrm{MPa}])-73.71 \text {. }
$$

Roxboroug (1987) basing on works carried out in different mines and tunnels in The United Kingdom and Australia, considers that the uniaxial compressive strength can provide a good specific cut energy index (Kinuthia et al. 2009).

In tunnel and mining gallery excavation by TBM, we emphasize the empiric prediction methods of the Norwegian Institute of Technology (NHT) (Rostami et al. 1996), the mathematical methods of the Colorado School of Mines (CSM) (Ozdemir 2003), the net penetration parameters $P$ and the penetration index $I p$. $P$ is the relation between the average advance $V$ and the rotation velocity $\omega$ in Eq. (5) and at the same time it is related to the rock mass geotechnical quality since the more breakage strength is the less is the TBM penetration. Additionally, the rock mass structural disposition should be taken into account (in this research the mean RMR measured in the working face is $\geq 42$ ).

$$
P(\mathrm{~mm} / \mathrm{rpm})=\frac{V(\mathrm{~mm} / \mathrm{min})}{\omega(\mathrm{rpm})} .
$$

Ip represents the pushing that needs to be transmitted to a cutter $S c$ to penetrate $1 \mathrm{~mm}$ per revolution and it 
is also used for the indirect detection of the rock mass quality variations. For the igneous and metamorphic rocks drilled and characterised by both the fracturation density and fault zones, the $I p$ is directly proportional to their geotechnical quality. The same thing occurs for the specific rotation energy although with different magnitude order.

$$
I p(k N / m m)=\frac{S c(k N)}{P(m m)} .
$$

Based on our experiences in underground works and later as researchers in TBM tunnel execution we have contributed the mathematical relations, which can help the setting up of the prediction methods and systems.

\subsection{Relations for Percussion Drilling}

During the excavation phase in Cabrejas tunnel in Guadarrama mountain chain (Spain), rock geomechanical characteristics in relation to boreability, which were different from the ones predicted in the project, were observed. For this reason, for example, it was sometimes necessary to change the predicted excavation system, turning from mechanical excavation to excavation by explosives.

In Table 1 the mean compressive strength value, for different types of rocks crossed while driving the tunnel, is shown.

Table 1. Compressive strength of different types of rock

\begin{tabular}{l|c}
\hline \multicolumn{1}{c|}{ Types of rock } & $\begin{array}{c}\text { Compressive strength } \\
(\mathrm{MPa})\end{array}$ \\
\hline Sandstone & 10.1 \\
\hline Lutite and dispersed gypsum & 4.5 \\
\hline Lutite & 6.3 \\
\hline Igneous rocks & 90 \\
\hline Lutitic sandstone & 5.2 \\
\hline Lutite with intercalated sandstone & 17.3 \\
\hline
\end{tabular}

In order to avoid the latter and to establish a prediction model to get knowledge of the rock type in front of the excavation, a follow-up and rock resistance control during the excavation was carried out by normalized trials, such as the uniaxial compressive strength over the rock sample (Fig. 2). In Fig. 3 the unconfined uniaxial compressive strength mean values carried out by the Franklin test, in a total of 460 trials are shown.

In this tunnel excavation, a jumbo equipped with a data register system (DPR), which registers (Fig. 4) the advancing depth $(\mathrm{mm})$, the penetration velocity $(\mathrm{dm} / \mathrm{min})$ (PR), the percussion pressure (HP), the advance pressure (FP) and the damping pressure (bar) (DP), the rotation velocity (r.p.m.) (RS), the rotation pressure or force (bar) (RP) and both water flow (1/min) (WF) and pressure (bar) (WP) was used.

By analyzing the different parameters obtained by the drilling registers (Fig. 5) the specific energy, the standard deviation specific energy, the uniaxial compressive strength and the specific destruction energy throughout

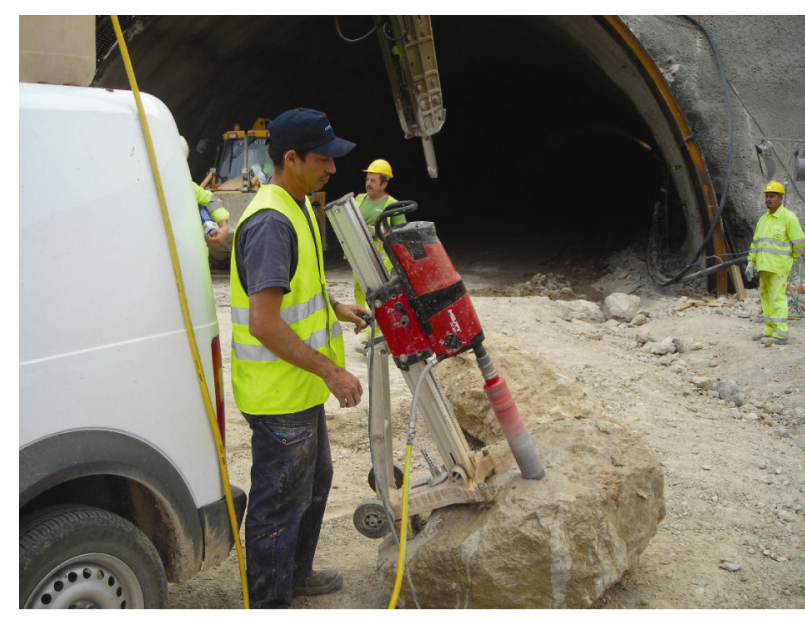

Fig. 2. Extraction of rock sample from blocks generated in excavation front blasting

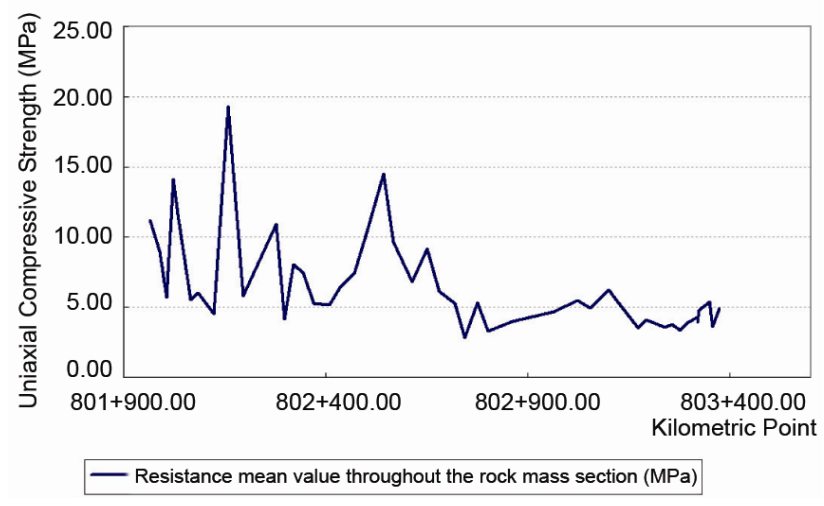

Fig. 3. Unconfined uniaxial compressive strength by Franklin test

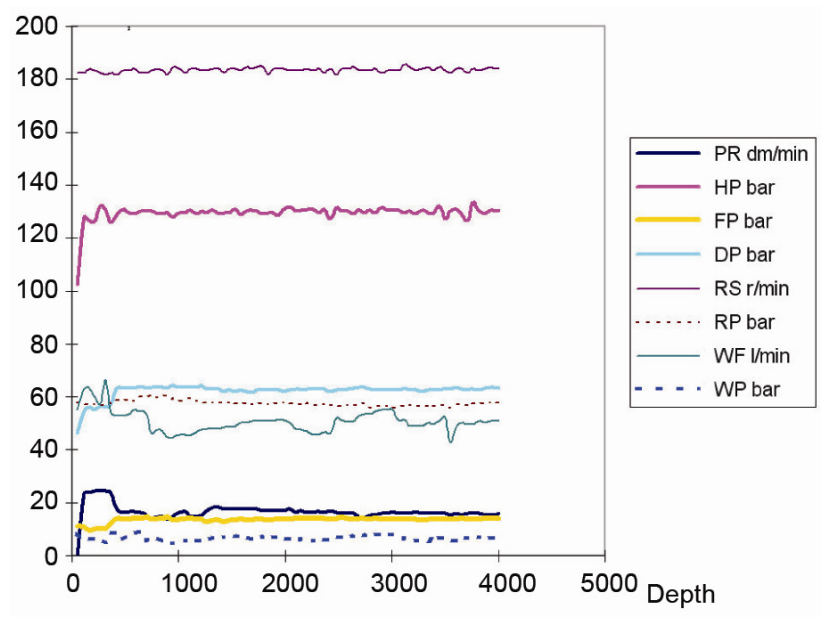

Fig. 4. MWD graphic registration outlet in a $4 \mathrm{~m}$. drill hole

the tunnel can be represented. The specific cut energy parameter is calculated according to Teale (1965) and the specific destruction energy parameter is calculated according to Thuro (1997).

In this figure, it can be seen that in the presence of cemented sandstone layer introduced in lutite rock, (Fig. 5) the average register of specific energy, the uniaxial compressive strength and the specific destruction energy, rise, 


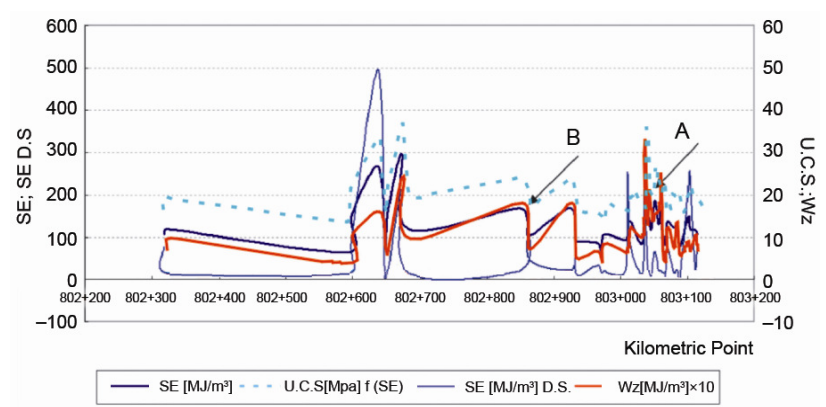

Fig. 5. Specific Cut Energy (MJ/m³ divided by 10), Compressive Strength (Mpa) and Destruction Energy $\left(\mathrm{MJ} / \mathrm{m}^{3}\right.$ multiplied by 10$)$

(kilometric point (KP) 803+040, marked with an A arrow) which indicates a rock mass geotechnical quality improvement. The specific energy standard deviation curve is high, which indicates a significant dispersion, owing to the material heterogeneity (sandstone and lutite rock).

On the other hand, in the KP $802+849$ case (indicated by a B arrow), the specific energy ( $S E)$, the uniaxial compressive strength (U.C.S.) and the specific destruction energy $\left(W_{z}\right)$ values, drop, indicating a disminution in rock mass geotechnical quality. As in the latter case the specific energy standard deviation curve ascending peak denotes a significant data dispersion which corresponds to the material heterogeneity.

In Figs 6 and 7, registers of the specific cut energy $(S E)$, the uniaxial compressive strength (U.C.S.) and the rock specific destruction energy $\left(W_{z}\right)$ as a sample of a perforated drill hole representative of those carried out in the tunnel, are shown.

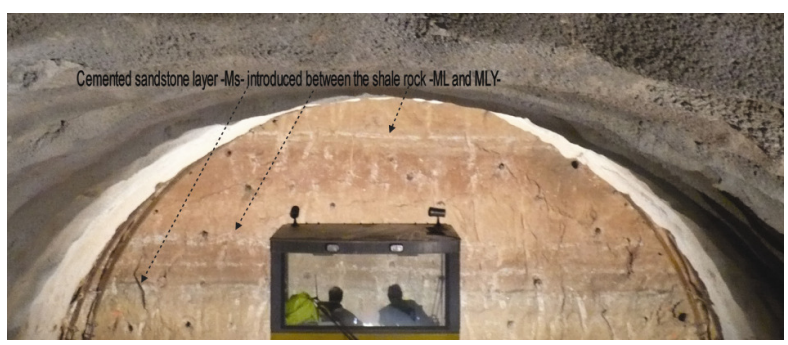

Fig. 6. Front advance with horizontal lutite stratification more or less rich in gypsum (ML, MLY) and cemented sandstone layers (Ms)

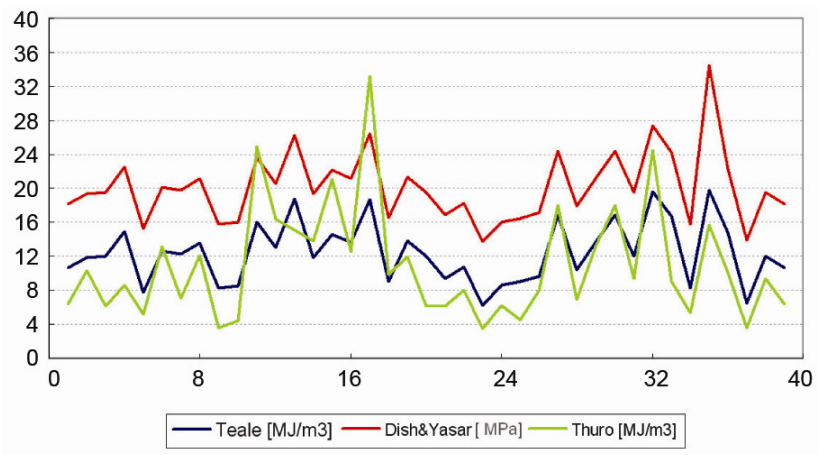

Fig. 7. Specific Cut Energy, according to Teale $\left(\mathrm{MJ} / \mathrm{m}^{3}\right.$ divided by 10 ), Compressive Strength (MPa) and Destruction Energy, according to Thuro $\left(\mathrm{MJ} / \mathrm{m}^{3}\right.$ multiplied by 10$)$

\subsection{Relations for TBM Excavation}

Taking into account that in the tunnel boring machine case, the excavation is carried out by penetration, the specific pressure energy and the specific rotation energy can be related to the excavated rock mass geotechnical quality and in particular with the penetration index. In Fig. 8 this relationship in a tunnel executed in Guadarrama mountain chain, in Spain, at a length of $8,917 \mathrm{me}-$ tres and $9,450 \mathrm{~mm}$ in diameter, is shown. It is excavated over both plutonic rocks (granite) and metamorphic rocks (gneiss, schist, calcic silicate rock) with a more recent geological structure rising in Tertiary Alpine Orogeny. The TBM machine has a $3,500 \mathrm{~kW}$ cutting power, a torque of $14,216 \mathrm{kNm}, 53$ simple discs and 4 double discs, all 17 inches in diameter.

Based on a 14,200 measurement campaign we have obtained the relationship between the specific excavation energy and the rock mass characterization through the RMR or Bieniawski index. The correlation between the two indicated parameters and the application of this correlation to new excavation fronts (Tardáguila and Suarez 2007) are shown in Fig. 9.

In Fig. 10 a hard rock mass which marks the cutting trail and slab formation is shown. In Fig. 11 a low quality rock mass is shown.

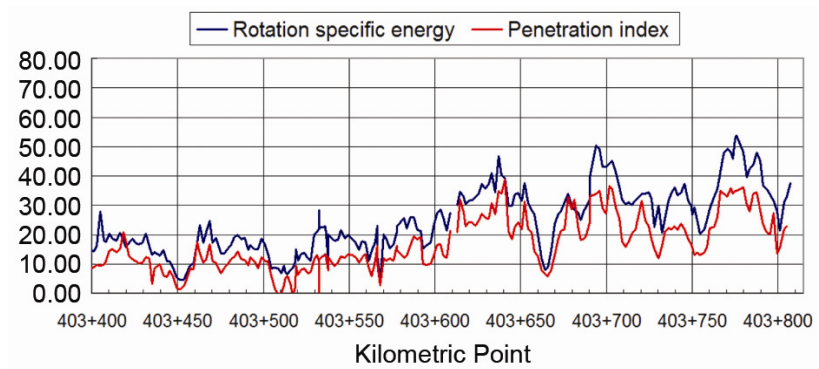

Fig. 8. Relations between the rotation energy and the perforation index

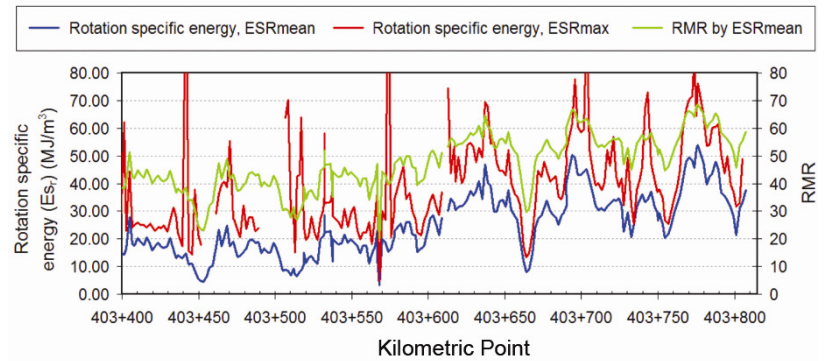

Fig. 9. Relation between rotation energy and RMR

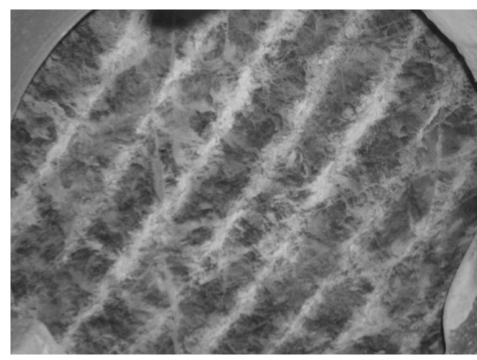

Fig. 10. Trail in sound rock 
Important relationship between the specific cut energy and the penetration index (Fig. 12) as well as the relationship between the specific cut energy and the RMR geomechanical index (Fig. 13) were achieved from the data and the relations obtained.

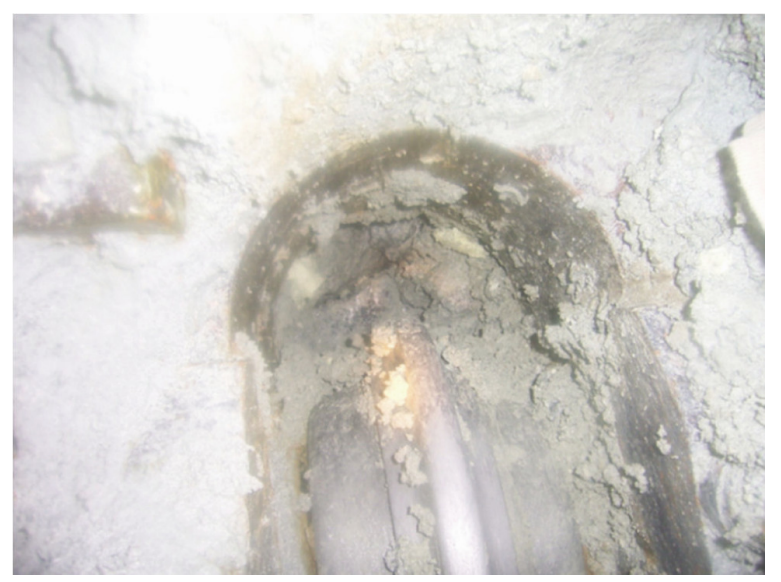

Fig. 11.Trail in low quality rock

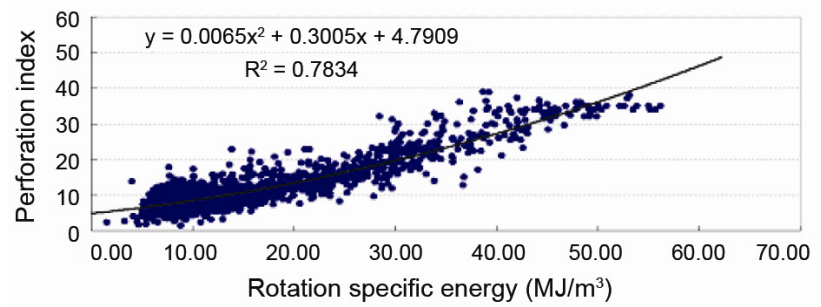

Fig. 12. Relationship between specific rotation energy and perforation index

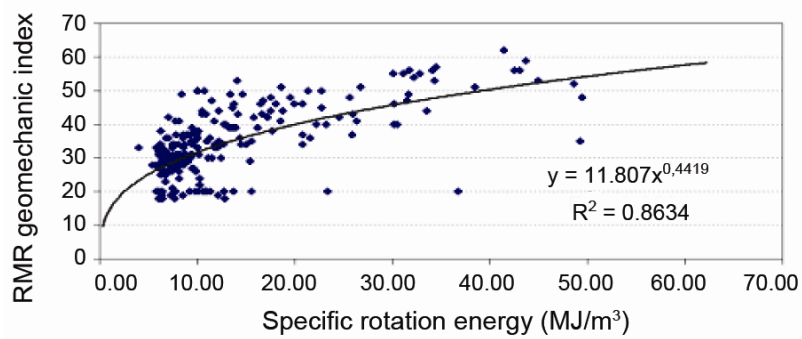

Fig. 13. Relationship between specific rotation energy and RMR index

\section{Rotation Drilling by Tricone Bit. Fuzzy Logic Models}

\subsection{Tricone Bit Drilling Concepts}

In Fig. 14, an operating drilling machine, where the rotation head and the hydraulic cylinders exert, together with the drilling string bar and their pressure over the cutting element, is shown.

In our research, the cutting element is a tricone bit which consists of three cones each one of them with a bit series that can be made of steel for soft rock and tungsten carbide for hard rock (Fig. 15). When the tricone bit body is turning, the cones roll at the bore hole bottom and the rock breakage is carried out by the bits (Fig. 16).

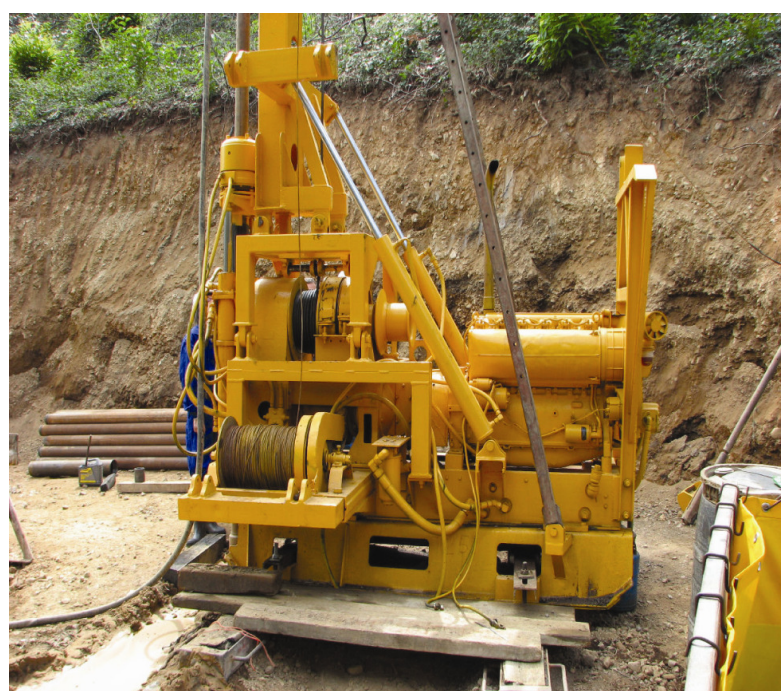

Fig. 14. Parts of perforation machine
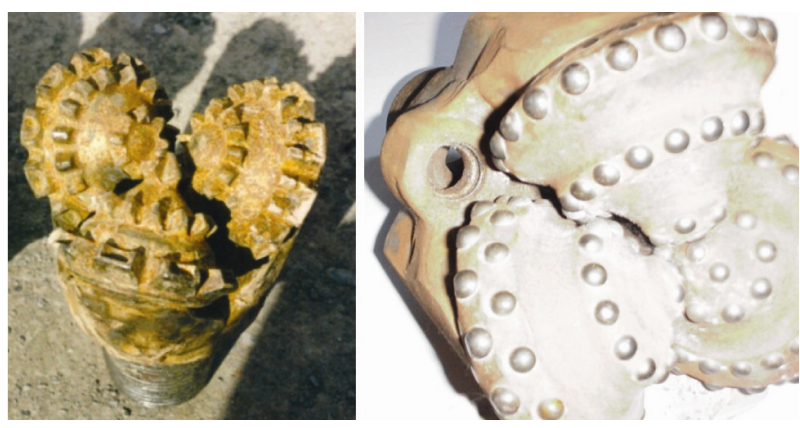

Fig. 15. Tricone bit differences in soft and hard rocks

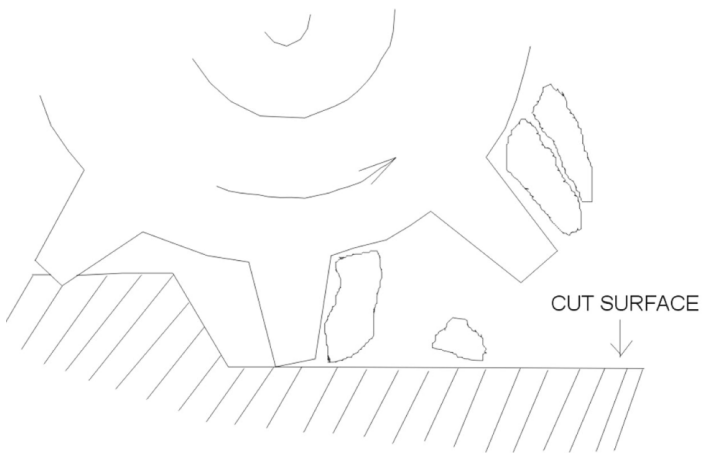

Fig. 16. Rock cutting action by the tricone bits

Therefore, for an efficient drilling in a rock formation with a determined strength, the weight parameter on the tricone bit, the rotation velocity and the bore hole diameter are adequately combined.

At the beginning of the drilling, when the applied pressure is insufficient to surpass the rock compression resistance, this suffers a breakage in small fragments with an abrasive effect. As the pressure increases and the rock compression strength is surpassed, the bit penetration in the rock is produced, increasing both the detritus (well cuttings) size and the penetration velocity. If the pressure continues, the tricone bit could be buried in the rock, besides, an additional pressure is hardly noted in the penetration velocity. 
Soft rocks do not need excessive load on the tricone bit, so, the tricone bit rotation velocity must be increased to obtain an adequate drilling velocity. In hard rock formations, the use of heavy loading, in order to surpass the rock strength, and not excessive velocities, which could provoke bit breakage, are necessary.

\subsection{Fuzzy Logic Model}

\subsubsection{Introduction}

According to Wang (1992) and Kosko (1994), the fuzzy models are in general, approximation functions, this means that they can be used in order to approximate a function or relation with the desired grade of exactitude (Grima 2000).

In a classical set system an element can belong or not belong to the set system, on the contrary, a fuzzy set consists of objects and their corresponding membership grade to a linguistic variable of the system. Therefore, the transition between a system member and another one that does not belong to this system is gradual.

A linguistic variable (Grima 2000), is characterized by a quintuple $L=(x, T(x), X, G, \mathrm{M})$, in which $x$ is the name of the variable, $T(x)$ is the term set of $x, G$ is a syntactic rule for generating the name - values of $x$, and $M$ is a semantic rule for associating each value of $x$ with its meaning (Zadeh 1975, 1965).

If the membership function value is equal to $1, x$ totally belongs to the fuzzy set. If the membership function value is equal to $0, x$ does not belong to the system and if the value is between 0 and $1, x$ is a partial member of the system. The membership function assignation to the fuzzy set is subjective by nature. Its type and shape mostly depends on the available data, the expert knowledge which defines the quality function and the context in which our study is included (Grima 2000; Klose 2002; Demicco and Klir 2004).

A fuzzy model consists of the following parts:

- a fuzzifier (encoder);

- basic knowledge which contains basic data, basic rules and inference tool;

- a defuzzifier (decoder). values.

The fuzzifier converts numerical data into linguistic

The knowledge which includes database and system knowledge is analyzed by linguistic fuzzy IF - THEN rules. The fuzzy inference mechanism which is also known as fuzzy reasoning is the core of a fuzzy model. The main function is to approximately emulate human reasoning which implicates a high abstraction level.

The defuzzifier is used to translate a fuzzy set into a numerical value (Toraño et al. 2008).

The fuzzy set membership function shape can be lineal (trapezoidal or triangular) or no lineal forms, which are still more sophisticated and complex, and which can hypothetically provide better results in some applications which do not have sufficient robustness in order to be later implemented in Microsoft Excel (MS Excel) (Ross 1995).
Trapezoidal membership function was used in this study (Fig. 17), which is characterized by four parameters $(a, b, c, d)$, also known as singular points, and are expressed as:

$$
\mu(x ; a, b, c)=\max \left(\min \left(\frac{x-a}{b-a}, 1 \frac{d-x}{d-c}\right), 0\right) .
$$

In this equation, when ' $b$ ' is equal to ' $c$ ', the trapezoidal membership function becomes triangular. As can be observed in Fig. 18, both points ' $a$ ' and ' $d$ ' always define the fuzzy set base whereas ' $b$ ' and ' $c$ ' define its own form (Toraño et al. 2008). Different membership function shapes can also be obtained according to the ' $a$ ', ' $b$ ', ' $c$ ' and ' $d$ ' parameters variation.

The fuzzy proposition which allows describing the relation between the input linguistic variables and the output linguistic variable by means of conditional fuzzy rules is an important fuzzy logic concept.

Theoretically, a fuzzy model formed by ' $x$ ' linguistic variables and ' $z$ ' membership functions will have a ' $Y$ ' fuzzy rules number (Toraño et al. 2008):

$$
Y=z^{x} .
$$

These rules can be complex and it is easy to make a mistake when being enunciated. For this reason, the high rule number obtained in the linguistic variables and the membership function combination should be supported by a software system such as the MS Excel in order to be implemented.

A fuzzy rule is normally formed by a premise and a consequent part (IF premise, THEN consequent), for example, IF the slope is 'high', THEN the effort is 'big', where the terms 'high' and 'big' can be represented by fuzzy sets or membership functions.

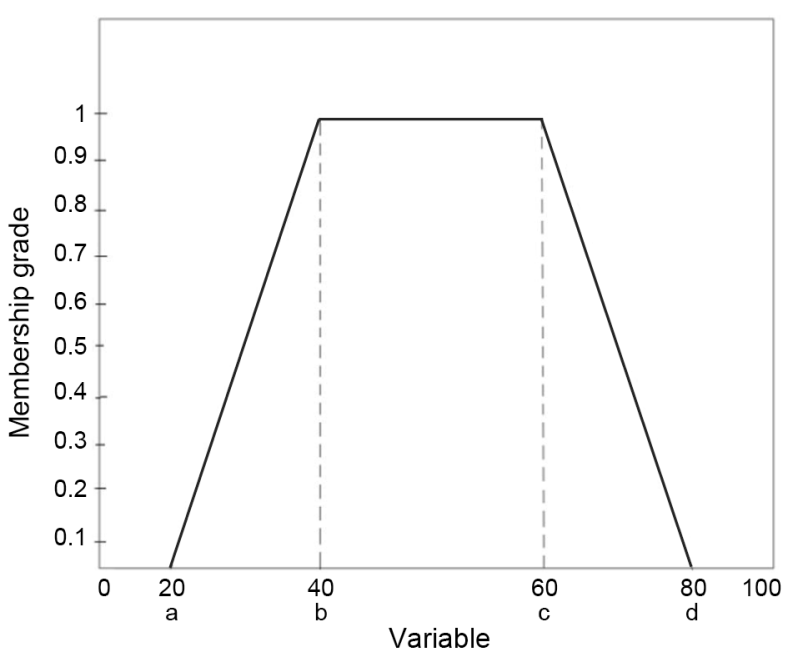

Fig. 17. Trapezoidal membership function
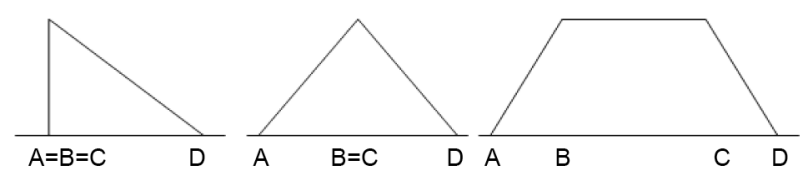

Fig. 18. Different morphologies that can be adopted by a membership function 
The fuzzy logic approximate reasoning inference mechanism, is based on the rules which agree with the inference (Demicco and Klir 2004). An output linguistic variable is obtained providing the rules and the input linguistic variables by the usage of this inference mechanism.

In this study, Takagi - Sugeno - Kang (Sugeno 1999) algorithm was used (TSK). The TSK fuzzy model can be seen as a linguistic and mathematical modelling combination. The main aim of Takagi - Sugeno - Kang was to be able to automatically construct fuzzy models based on measured data. The TSK fuzzy model can define a high non lineal functional relation by using a small number of IF - THEN rules. This is advantageous, particularly if the system input variable number is high. The TSK fuzzy model mathematically takes the following form:

$$
R_{i} \text { : If } x \text { is } A_{\mathrm{i}} \text { then } y_{i}=f_{i}(x), i=1,2, \ldots \ldots K,
$$

where $R_{i}$ denotes the rule $i, K$ is the rule number, $x$ is the input variable, $y$ is the output variable and $A_{i}$ is the fuzzy set defined in the $x$ input linguistic variable.

Due to the fact of having field measurement data, this model has been chosen as the most adequate (Toraño et al. 2008). In the fuzzy model construction the following four important stages should be carried out:

1 - Selection of the input and output variable;

2 - Selection of the model type which will be used, for example, the Takagi - Sugeno - Kang model. The selection mainly depends on the considered problem;

3 - Selection of the membership function type and number;

4 - Selection of the inference mechanism, the fuzzy operators and the defuzzification methods.

\subsubsection{Fuzzy Model in Rock Formation Prediction}

The designed fuzzy model in rock formation prediction, using easy access programs for designers and technicians were used; on the one hand, the MATLAB program (Matlab 2001) and on the other hand, a program designed and implemented in MS Excel by us (Toraño et al. 2008). In the case of the tricone bit perforation the tricone bit revolution per minute (r.p.m.) and the weight exerted over the tricone bit in each diameter unit (lb/inch) have been used as input parameters. These values are based on our experiences as researchers and on field measurement data.

In Fig. 19 the input and output variables are shown. The fuzzy inference system (FIS) was used in order to establish the input and output variables. These variables, were passed on to the fuzzy logic language by using available software tools. The fuzzy function defines how each input space point is transformed in a variable value between 0 and 1 .

The tricone bit revolution per minute is the input linguistic variable called 1 , and is divided into four types: very low (0-100 r.p.m.), low (65-125 r.p.m.), medium (100-212.5 r.p.m.) and high (125-350 r.p.m.). The corresponding member ship functions are shown in Fig. 20.
The weight exerted on the tricone bit is the input linguistic variable called 2 which is divided into four ranges: very low $(0-1800 \mathrm{lb} / \mathrm{inch})$, low $(900-3200 \mathrm{lb} /$ inch $)$, medium (1800-5000 lb/inch) and high (3200-6000 lb/inch). The different membership functions are shown in Fig. 21. There are four ranges in the output linguistic variable corresponding to the compressive strength of the type of rock. Values between 1 and $12.5 \mathrm{MPa}$ are considered in very soft rocks, 6.75 and $37.5 \mathrm{MPa}$ in soft rocks, 22 and $75 \mathrm{MPa}$ in medium rocks and 48.5 and $100 \mathrm{MPa}$ in hard rocks (Fig. 22). All these ranges have been defined based on experiences and field measurements.

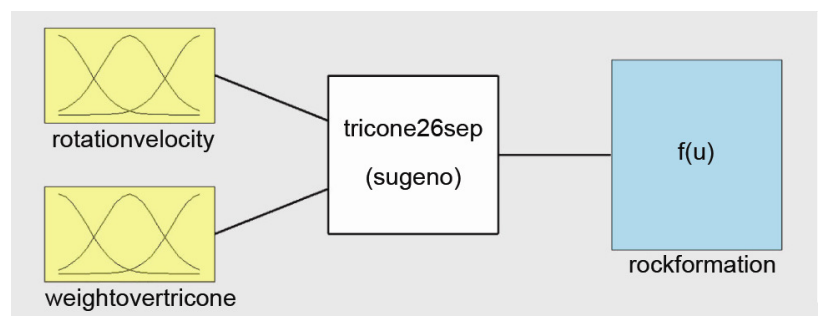

Fig. 19. Model input and output variable definition by using fuzzy inference system (FIS)

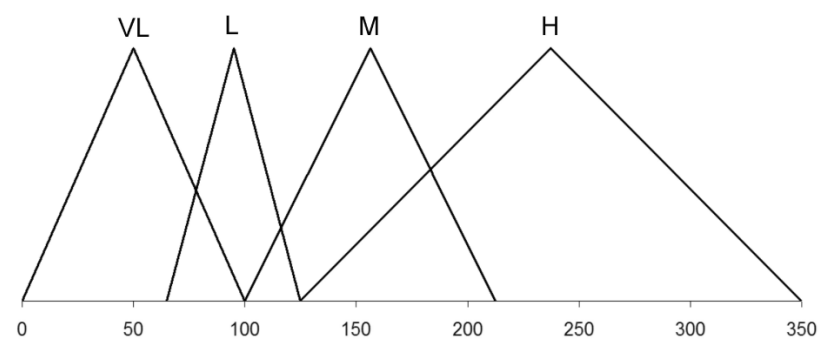

Fig. 20. Membership functions of tricone bit rotation velocity input variable in r.p.m

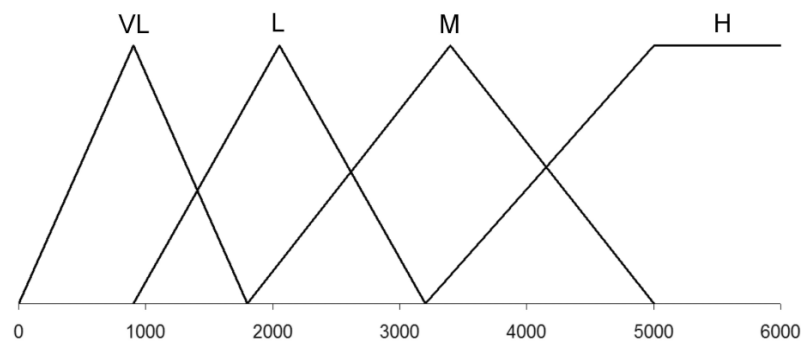

Fig. 21. Membership functions of weight over tricone bit input variable in $\mathrm{lb} / \mathrm{inch}$

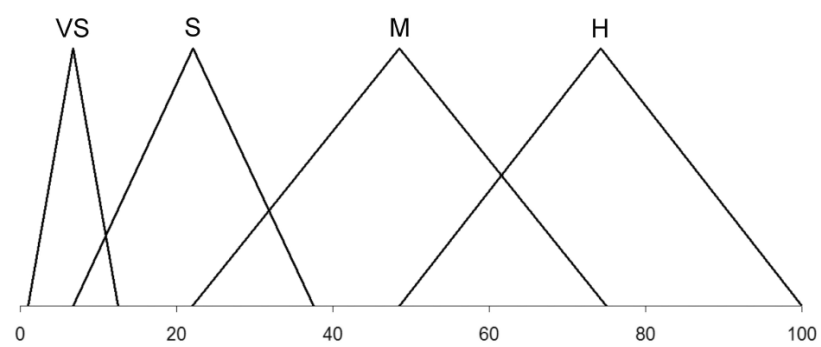

Fig. 22. Membership functions of output variable in Mpa 
In order to carry out the inference in a fuzzy model rule, the fuzzy propositions should be represented by a consequent function (IF-THEN rule), where $\mathrm{A}$ and $\mathrm{B}$ are the linguistic values represented by the fuzzy sets (Acaroglu et al. 2008). The use of these fuzzy sets provides the generalization of the information used to describe the system behaviour. In this model a total of 16 IF - THEN rules were used (Fig. 23). In Fig. 24 the corresponding fuzzy rules viewer is shown.

The Takagi - Sugeno - Kang algorithm that has been used in this research can calculate the type of rock which is being cut, as it is capable of interpolating the input parameters.

In order to compare the real data with those obtained through fuzzy logic, the total IF - THEN rules priorly defined through MATLAB software were implemented through MS Excel

The representation of the input variables in MS Excel is based on the definition of the ranges for each input variable and by combining these input variables through IF - THEN rules, the output variable value (Type of Rock) is obtained. For example, for 175 revolutions per minute and 3,500 pounds in weight per diameter inch on the tricone bit, a rock strength of $41.92 \mathrm{MPa}$ is obtained (a medium rock strength) (Fig. 25).

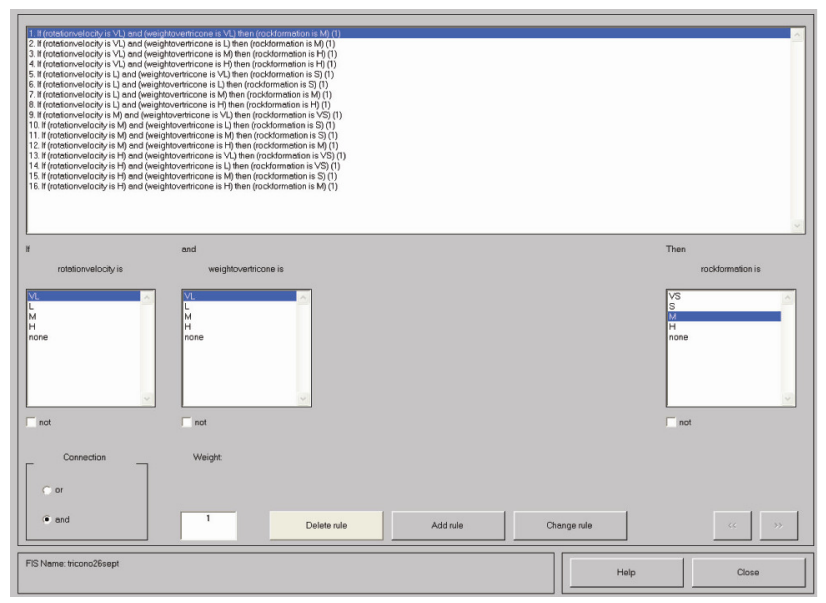

Fig. 23. IF - THEN rules defined for the model

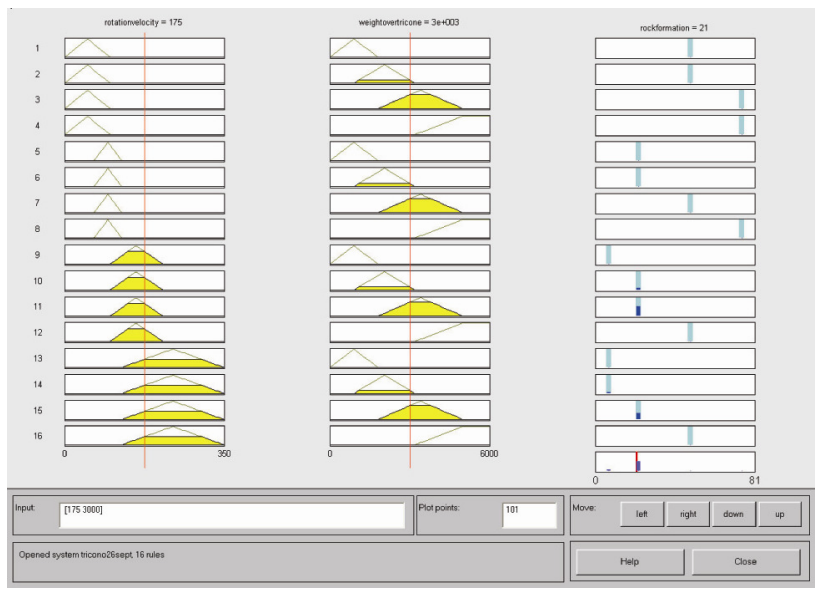

Fig. 24. Fuzzy rules viewer

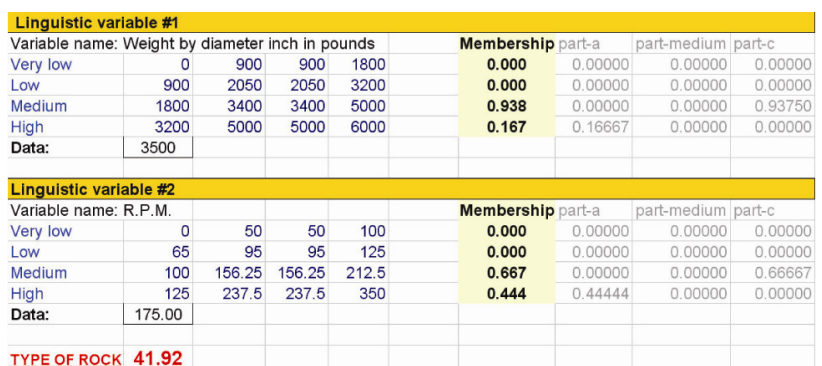

TYPE OF ROCK 41.92

Fig. 25. Use of the Microsoft Office Excel tool in rock type calculation which is being perforated

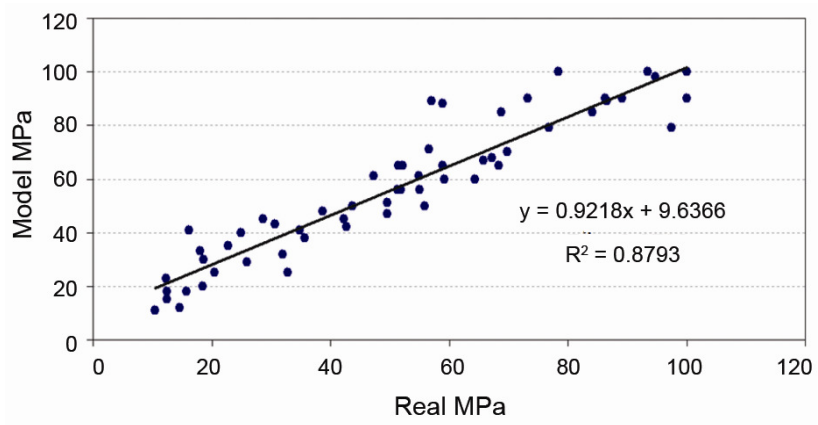

Fig. 26. Adjustment graph between real hardness rock values and those calculated by the model

A comparison between field measurement values and Fuzzy Logic model values show a good adjustment (Fig. 26).

\section{Conclusions}

A very important aspect in tunnel excavation is to predict the geological and geomechanical characteristics in the front of the tunnel excavation, particularly in sections where the rock formation is expected to change considerably, allowing operators to take adequate measures before reaching conflictive rock mass formations.

The prediction models, which are the basis of the automatic systems to be implemented in the drilling equipment, can be estimated through traditional mathematics, as it has been indicated at the beginning of this paper, or if this is not possible, through fuzzy logic models. In both methodologies model adjustments through wide measurement campaigns are fundamental.

In the first case, the perforability parameters recorded by the DPR tools and their adjustment by the corresponding measurement campaigns, allow us to predict the rock mass behaviour and to optimize the drilling parameters. The Specific Cut Energy, the Uniaxial Compressive Strength and the Specific Destruction Energy, play an important role in this prediction methodology.

In the Fuzzy Logic model, with a great possibility of application in mining and civil works and apart from the appropriate model selection, a wide experience on the equipment used, the role played by the chosen input variables with the possible combination between them, the range and weight and the relation to the output variables are fundamental. In our case, based on the rock material parameters and the machine parameters, a model vali- 
dated has been obtained. The model presented allows us to predict the type of rock perforated by easy access parameters.

\section{Acknowledgements}

The authors would like to thank Jorge Roldán Cardona, Technical Engineer for the information provided and taken from the Final Project of his carrier at the Technical Engineering School of Mines of Mieres (University of Oviedo) named 'The evaluation of the geotechnical conditions in the front face of the tunnel excavation front by using drilling data'.

The authors are grateful to Carbonar S.A. Mining Company for providing geotechnical - geological investigation bore whole campaign data carried out in July 2008.

\section{References}

Acaroglu, O.; Ozdemir, L.; Asbury, B. 2008. A fuzzy logic model to predict specific energy requirement for TBM performance prediction, Tunnelling and Underground Space Technology 23(5): 600-608. doi:10.1016/j.tust.2007.11.003

Demicco, R. V.; Klir, J. G. (Eds.). 2004. Fuzzy Logic in Geology. California: Academic Press. 347 p.

Ersoy, A. 2003. Automatic drilling control based on minimum drilling specific energy using PDC and WC bits, Mining Technology 112(2): 86-96. doi:10.1179/037178403225001629

Godo, L.; Jacas, J.; Valverde, L. 1989. Fuzzy values in fuzzy logic, in Proc. of the $3^{\text {rd }}$ IFSA Congress, "The Coming of Age of Fuzzy Logic”. Ed. by J. C. Bezdek. August 6-11, 1989, Seattle, USA, 1989, 829-832.

Grima, A. M. 2000. Neuro-Fuzzy Modelling Engineering Geology. Applications to mechanical rock excavation, rock strength estimation, and geological mapping. Delft University of Technology, Department of Applied Earth Sciences, Section of Engineering Geology. A. A. Balkema, Rotterdam, Brookfield. $245 \mathrm{p}$.

Kala, Z. 2008. Fuzzy probability analysis of the fatigue resistance of steel structural members under bending, Journal of Civil Engineering and Management 14(1): 67-72. doi:10.3846/1392-3730.2008.14.67-72

Kinuthia, J. M.; Snelson, D.; Gailius, A. 2009. Sustainable medium-strength concrete (CS-Concrete) from colliery spoil in South Wales UK, Journal of Civil Engineering and Management 15(2): 142-157. doi:10.3846/1392-3730.2009.15.149-157

Klose, Ch. D. 2002. Fuzzy rule-based expert system for shortrange seismic prediction, Computers \& Geosciences 28(3): 377-386. doi:10.1016/S0098-3004(01)00054-1

Kosko, B. 1994. Fuzzy systems as universal approximators, IEEE Transactions and Computers 43(11): 1329-1333. doi:10.1109/12.324566

Matlab, Fuzzy Logic Toolbox TM. 2001. The Mathworks.

Mellor, M. 1972. Normalization of specific energy, International Journal of Rock Mechanics and Science 9: 661663. doi:10.1016/0148-9062(72)90016-2

Mozaffari, S. 2007. Measurement While Drilling System in Aitik Mine: $\mathrm{PhD}$ thesis. School of Applied Geosciences and Mining, Lulea University of Technology, Sweden.
Nguyen, H. T.; Sugeno, M.; Tong, R. M.; Yager, R. R. (Eds.). 1995. Theoretical aspects of Fuzzy Control. New York: John Wiley \& Sons, Inc. 359 p.

Ozdemir, L. 2003. CSM Computer Model for TBM Performance Prediction. Colorado School of Mines, USA. 13 p.

Paithankar, A. G.; Misra, G. B. 1976. A critical appraisal of the Protodyakonov index, International Journal of Rock Mechanics and Mining Sciences \& Geomechanics Abstracts 13: 249-251. doi:10.1016/0148-9062(76)91545-X

Peck, J. P. 1989. Performance Monitoring of Rotary Blast Hole Drills: PhD thesis. McGill University Montreal, Quebec.

Raue, E.; Timmler, H.-G.; Garke, R. 2009. On the physically non-linear analysis of cyclic loaded reinforced concrete cross-sections with mathematical optimisation, Journal of Civil Engineering and Management 15(2): 189-195. doi:10.3846/1392-3730.2009.15.189-195

Reddish, D. J.; Yasar, E. 1996. A new portable rock strength index tested based on specific energy of drilling, International Journal of Rock Mechanics and Mineral Science 33(5): 543-548. doi:10.1016/0148-9062(95)00083-6

Ross, T. J. 1995. Fuzzy Logic with Engineering Applications. McGraw-Hill. 600 p.

Rostami, J.; Ozdemir, L.; Ilso, B. 1996. Comparison between CSM and NTH Hard Rock TBM Performance Prediction Models, in Proc. of Annual Technical Meeting of the Institute of Shaft Drilling Technology. Las Vegas, USA, 111.

Roxboroug, F. F. 1987. The role of some basic rock properties in assessing cuttability, in Proc. of Seminar on Tunnels, Wholly Engineered Structures. I. E. Aust, AFCC, April 47, 1987. The University of New Wales, Sydney, Australia, $1-21$.

Schunnesson, H. 1997. Drill process monitoring in percussive drilling for location of structural features, lithological boundaries and rock properties, and for drill productivity evaluation: $\mathrm{PhD}$ thesis. Lulea: Lulea University of Technology, Sweden.

Scoble, M. J.; J. Peck, J. C.; Hendricks, C. 1989. Correlation between rotary drill performance parameters and borehole geophysical logging, Mining Science and Technology 8(3): 301-312. doi:10.1016/S0167-9031(89)90448-9

Sugeno, M. 1999. Fuzzy Control and Applications: Doctorate Program. Universidad Politécnica de Madrid, 1998-1999.

Tardáguila, I.; Suarez, J. L. 2007. Metodología para el seguimiento y control del terreno en el interior de los túneles de Guadarrama [Methodology for monitoring and control of land within the Guadarrama tunnel], in Ingeotúneles libro 12, capítulo 16 ["Ingeotúneles" book 12, Chapter 16], Entorno Gráfico [Graphical Environment], 329-360.

Teale, R. 1965. The concept of specific energy in rock drilling, International Journal of Rock Mechanics and Mining Sciences \& Geomechanics Abstracts 2(1): 57-73. doi:10.1016/0148-9062(65)90022-7

Toraño, J.; Diego, I.; Menendez, M.; Gent, M. 2008. A finite element method (FEM) - Fuzzy logic (Soft Computing): virtual reality model approach in coalface longwall mining simulation, Automation in Construction 17(4): 413424. doi:10.1016/j.autcon.2007.07.001

Thuro, K. 1997. Drillability prediction-geological influences in hard rock drilling blast tunnelling, Earth and Environment Science, Geolische Rundschau 86(2): 426-438. doi:10.1007/s005310050151 
Turtola, H. 2001. Utilization of Measurement While drilling to Optimize Blasting in Large Open Pit Mining. Licentiate Thesis, Lulea: Lulea University of Technology, Sweden.

Wang, L. X. 1992. Fuzzy systems are universal approximators, in Proc. of IEE International Conference on Fuzzy Systems (ICFS'92), March 8-12, 1992, San Diego, USA, 1163-1170. doi:10.1109/FUZZY.1992.258721
Zadeh, L. A. 1965. Fuzzy Sets, Information and Control 8(3): 338-353. doi:10.1016/S0019-9958(65)90241-X

Zadeh, L. A. 1975. Calculus of fuzzy restrictions, in Fuzzy sets and their applications to cognitive and decision processes, Ed. by L. A. Zadeh, K. S. Fu, K. Tanaka, M. Shimura. New York, USA: Academic Press, 1-39.

\section{MATEMATINIS IR NERAIŠKIOSIOS LOGIKOS MODELIAI APRAŠANT GEOLOGINES IR GEOMECHANINES UOLIENOS SAVYBES, NAUDOJANT POŽEMINIO KASINĖJIMO DUOMENIS}

\section{S. Torno, J. Toraño, M. Menéndez, M. Gent, J. Velasco}

Santrauka

Atliekant požeminius uolienų gręžimo darbus ir optimizuojant darbus bei jiems naudojamą irangą, labai svarbu prognozuoti geologines ir geomechanines uolienos savybes. Šiame darbe pateikiamos gautos matematinès išraiškos, taikant tunelių kasimo duomenis, gautus naudojant smūginio gręžimo ir tunelių gręžimo (TBM) įrangą. Šios matematinès išraiškos yra naudingos smūginio gręžimo metu koreguojant gręžimo parametro fiksavimo (DPR) duomenis, o naudojant TBM ịrangą - nustatant uolienos geomechanini indeksą (RMR). Atsižvelgiant i gautų matematinių modelių kompleksiškumą, t. y. i gautus parametrus ir jų sąryšius, naudotinas neraiškiosios logikos modelis, jungiantis parametrus, tinkamus trigalvio grąžto gręžimo įrangai.

Reikšminiai žodžiai: neraiškioji logika, tunelių gręžimo įranga, gręžimo parametro fiksavimas, trigalvis grąžtas.

Susana TORNO. PhD, Assistant lecturer in the School of Mines at Oviedo University, Spain. She obtained her PhD. in Mining, Civil Work and Environment in 2008 at that University. For the past 6 years Dr Torno has been working for the Mining Engineering and Civil Works Research Group. She is a reviewer for Environmental Fluid Mechanics (Springer) and Tunnelling and Underground Space Technology (Elsevier).

Javier TORAÑO. Prof. PhD. Professor in the School of Mines at Oviedo University, Spain. He leads the Mining Engineering and Civil Works Research Group of the School of Mines at Oviedo University. He has worked for over 20 years as a company director engineer in the most important mining companies in Spain. He has a wide research experience in the mentioned fields. He has frequently published and reviewed in the most prestigious international scientific journals, quoted in the Journal Citation Report, in Mining, Civil Works and Environmental fields.

Mario MENÉNDEZ. Prof. PhD. Professor of Mineral Processing in the School of Mines at Oviedo University, Spain. He is Director of this School at the present and he has been working for the Mining Engineering and Civil Works Research Group. He has some publications in the most prestigious international scientific journals in Mining, Civil Works and Environmental fields. He heads numerous research projects for different companies.

Malcolm GENT. PhD, lecturer of Mineral Processing in the School of Mines at Oviedo University, Spain. He has been working for the Mining Engineering and Civil Works Research Group since 2004. He has some publications in the most prestigious international scientific journals. He has been developing his research interests in the areas of Mining, Civil Works and Environment.

Judith VELASCO. PhD Student in the School of Mines at Oviedo University, Spain. She received her PhD on Mining, Civil Work and Environment in 2010 at Oviedo University. 